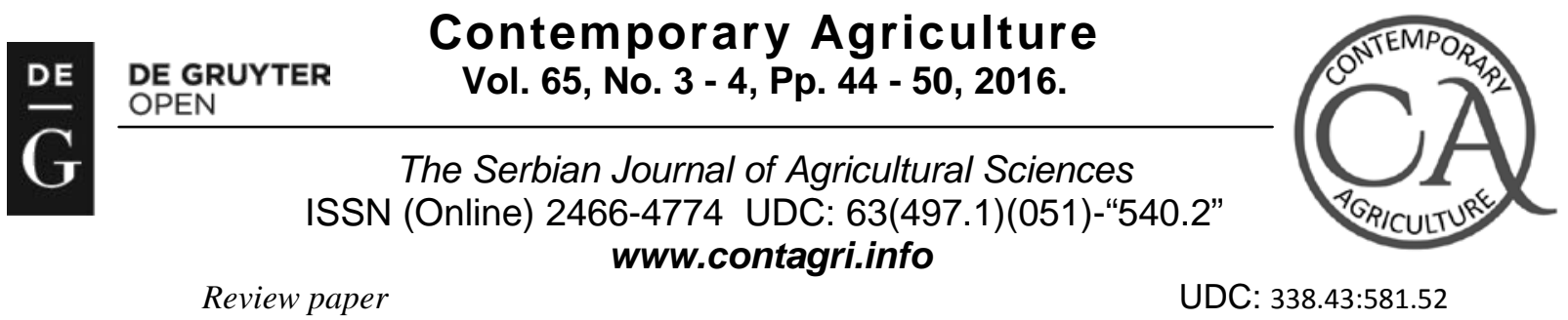

DOI: $10.1515 /$ contagri-2016-0017

\title{
INTERDEPENDENCE OF AGRICULTURAL PRODUCTION AND ENVIRONMENT AND THE ROAD TO SUSTAINABLE DEVELOPMENT
}

\author{
Jasmina CURIĆ, ${ }^{1}$ Bahrija KAČAR, ${ }^{2}$ Selma IKIĆ
}

\begin{abstract}
Summary: Sustainability of agricultural production in the world is in serious crisis. Interdependence of agricultural production and the environment is multiple and causality works both ways. On one hand, there are environmental changes which hamper food production, and on the other, the agricultural production, as it is, is severely damaging the environment. The very systems of agricultural production jeopardize future production. The goal of this paper is to explore causes of limitations of sustainable agricultural development in the world, where the authors emphasize the following: gas emissions with greenhouse effect, a disturbed cycle of nitrogen circulation and destruction of biodiversity.

We explored the factors of interdependence of environment and agricultural production and possibilities of sustainable development with a methodological frame work of research, analyzing, comparing and synthesizing domestic and international literature. The authors propose a holistic approach to sustainable development, carefully suited to the regional and local circumstances.
\end{abstract}

Key words: agriculture, environment, sustainable development

\section{INTRODUCTION}

There are 7200000000 people living on our planet, nine times more than in 1750, at the beginning of the Industrial Revolution, when Earth numbered 800000 000. The world population is constantly increasing by 75000 000 a year. Very soon, in 2020, the population will reach 8 billion, and estimates are that it will reach 9 billion in 2040 (Sustainable Development Solutions Network SDSN, 2013).

One of the most complex unsolved issues of modern world is how the world will feed itself. Many considered the issue resolved with major breakthroughs in food production, based on scientific achievements. Especially after the green revolution which started back in the sixties, when highly productive crops were introduced, and it seemed that the food production would exceed Earth's population. Now we have considerable doubts about that.

Warnings related to this problem have been heard for over two centuries, when Thomas Robert Maltus wrote in 1798, in his Essay on population principles, facing us with the challenge of supplying food to ever increasing population.

At the beginning of the Industrial Revolution, production per capita significantly increased (Madison 2006). World economy was increasing quickly and reached enormous proportions, for today its annual output, called Gross World Production, is 90 trillion US \$, roughly 200 times of that in 1750. The world economy has enormous proportions and is quickly growing, at a rate of $3-4 \%$ a year.

Environmental threats appear on several fronts, mankind has been changing the Earth's climate, availability of pure water, chemical composition of the oceans and habitats of other species. This impact is so big today that our planet is experiencing obvious changes in major processes which affect cycles of water, nitrogen and carbon. We do not know the exact extent, time frame and implications of these changes, but we do know enough to understand they are dangerous and unprecedented in ten millennia of our civilization. Thus we come to sustainable development. In interactive terms, sustainable development represents an attempt to understand interactions of three complex systems - world economy, global society and the environment.

Review paper / Pregledni rad

${ }^{1}$ Jasmina Curić, Ph.D., Assistant, Department for Chemical - Technological sciences, State University of Novi Pazar, Serbia,

${ }^{2}$ Bahrija Kačar, Ph.D., Assistant, Department for Economic sciences, State University of Novi Pazar, Serbia,

${ }^{3}$ Selma Ikić, M.Sc., associate , Office for Local Economic Development, City Administration of Novi Pazar, Serbia

Corresponding author: Jasmina Curić, E-mail: jasminacuric65@gmail.com, Phone: +381 666315 270, 
From the view of anthropogenic environmental changes, the most important sector is agriculture. Many believe that major sources of the damage are power plants and traffic. These really are major sources of global environmental unsustainability but infamous title of major single cause of environmental damage goes to food production (SDSN, 2013).

The problem we face is that food supply is hampered by anthropogenic environmental changes, where single biggest source are systems of agricultural production. In other words, the very systems of agricultural production jeopardize their own future production.

Because the systems of agricultural production throughout the world differ greatly, we will need to solve the problems locally in order to harmonize systems of agricultural production with environment protection and preservation of ecosystems and biodiversity.

\section{THE IMPACT OF ENVIRONMENTAL CHANGES ON AGRICULTURAL PRODUCTION}

Systems of agricultural production almost everywhere in the world are faced with enormous stress, and that is why they cannot economically and sustainably provide healthy food and to meet demands of the population neither locally nor globally.

Major challenge which will additionally complicate the problems is that the world population is still relatively quickly increasing, even in absolute number. It increases by 75 million every year, so the estimates are that the world population by 2025 will be 8 billion.

Second important challenge represents environmental threats which will hamper food production in many parts of the world. These environmental threats will appear in different shapes. The biggest ones are climate changes (Kramer and Meeusen, 2003). Due to anthropogenic greenhouse gases effect, complex climate changes occur, which will have a negative impact on food production in many parts of the world. Higher temperatures will have negative impact on food production in warmer climate. The crops will be exposed to temperature stress, especially in poorest, tropical parts of the world. At higher temperatures, crops can fail, due to respiration and inability to grow. Higher temperatures have a negative impact on soil humidity, which jeopardizes crop productivity. Warming will be followed with changes in patterns of regional and global precipitations.

Many parts of the world will be drier, and in some already dry regions, growing crops will become impossible. In regions with high precipitation rate we could see floods and extreme tropical storms. Climate changes will raise the sea level. Some coastal regions harvested today will be exposed.

Carbon dioxide emissions do not only cause climate changes, they directly impact ocean acidification. Ocean acidification also has serious consequences for food supply, since it endangers sea flora and fauna. Higher acidification of ocean has a consequence of smaller and deformed mollusks; therefore acidity will hamper formation of crust composed of calcium carbonate. In many marine environments flora and fauna will be endangered, and it has negative impact on biodiversity and human diet.

Swift degradation of soil, loss of surface layer and nutrient depletion are consequences of intensive farming. The most significant threats to food production are the processes of soil degradation, extreme hydrological events and unfavorable changes of biochemical element circulation. Their comprehensive control must be a priority for sustainable development and environment preservation (Varallyay, 2011).

Environmental stress jeopardizes irrigated areas which provide disproportionately big world crop production. The current system of irrigation depends on fresh waters - rivers, glaciers and underground waters, which are jeopardized by over-exploitation and anthropogenic climate changes. Glaciers recede due to warmer climate. Their meltdown can temporarily increase water flows and food production, but water inflow will disappear together with them. Many great rivers are so exploited they can no longer reach the sea. In Northern China, people living off Yangtze are already suffering due to decrease of river flow and the fact it does not reach the ocean.

The same happens with Rio Grande, the river where water volume has significantly decreased in Northern Mexico, resulting in decrease in food production in the area. One of the most significant warnings of water shortage which is awaiting the 21st century due to global warming, increase of population and pollution has been set forth by a world food expert Lester Brown.

In his opening speech on Water Conference in Stockholm back in 2000 - "How water shortage will shape the world" - Brown sets forth the data that total water consumption has doubled in the last 50 years. Due to increased food demand, with lack of surface waters, there has been overconsumption of underground waters for irrigation.

Since underground waters are slow to recuperate, their level on all continents has fallen. One can roughly estimate that of all exploited waters, whether underground or surface ones, $70 \%$ is used for irrigation, $20 \%$ in industry and $10 \%$ for households (Ilic et al, 2011). Water shortage is particularly felt in Northern Africa (Morocco, Algiers, Tunisia, Libya and Egypt) and Middle East. 
These countries import huge quantities of wheat the production of which requires enormous quantities of water. By importing wheat, we help distribute water globally.

Using methodology of European Environment Agency (EEA) of creating and calculating indicators defining sustainable use of natural resources we can oversee the extent of exploitation of individual resources. An example of such an indicator is Water Exploitation Index (WEI).

WEI shows that serious problems can occur if the index surpasses $20 \%$ and $40 \%$ is deemed borderline of extreme water stress. A total of 20 countries (50\% of European population) have and index of less than $20 \%$ and are considered non-critical in water exploitation. Six countries (32\% of European population) have a mild stress exploitation of water resources: Romania, Belgium, Denmark, Greece, Turkey and Portugal. Finally, there are four countries (18\% of European population) with an extreme water stress: Cyprus, Malta, Italy and Spain.

All above mentioned environmental threats - climate changes, ocean acidification, chemical pollution, glacier reduction, over-exploitation of water resources, show the fact that food production systems depend on climate and environment more than any other human activity. When considering population increase and greater environmental stress, we will understand immensity of challenges regarding food supply, which await us.

\section{IMPACT OF AGRICULTURAL PRODUCTION ON ENVIRONMENTAL CHANGES}

Of 130 million square kilometers of soil on Earth, man is already using considerable portion. Approximately $40 \%$ of total land in the world, 50000000 square kilometers, are used for agricultural production. Some 14 million square kilometers are arable agricultural land, i.e. land used for crop production, totaling $10 \%$ of land surface in the world. Pastures and meadows cover more than 34 million square kilometers, 25\% of total land. Forests cover 39 million square kilometers, $30 \%$ of land.

What pressure does agriculture put on the environment? These are primarily greenhouse gas emissions. The agricultural sector (including deforestation for new pastures and plantations) is the major emitter of all three major gases: carbon-dioxide, methane and nitrogen-sub oxide. although agricultural emissions are mostly related to methane production from cultivating rice and cattle-breeding, main possibilities for reducing greenhouse gases in agricultural sector mean reducing CO2, due to huge quantities of soil used globally in agriculture and in pastures. These kinds of soil are usually over-exploited, vegetation is destroyed and the soil is poor with nutrients when compared with types of uncultivated soil.

Table 1. Sources of gas emission with greenhouse effect by economy sectors in 2010

\begin{tabular}{|c|c|c|c|}
\hline A) DIRECT EMISSIONS(CO2 equivalents) & \multicolumn{2}{|c|}{ B) INDIRECT CO2 EMISSIONS } \\
\hline Electricity production & $25 \%$ & Energy & $1,4 \%$ \\
\hline Agriculture and forestry & $24 \%$ & Agriculture and forestry & $0,9 \%$ \\
\hline Buildings & $6,4 \%$ & Buildings & $12 \%$ \\
\hline Transport & $14 \%$ & Transport & $0,3 \%$ \\
\hline Industry & $21 \%$ & Industry & $11 \%$ \\
\hline Other energy sources & 9,6 & $/$ & $/$ \\
\hline
\end{tabular}

Source: Intergovernmental panel on climate change (IPCC) ARS Summary for Policymakers. Total anthropogenic GHG emissions by economic sectors.

Column A shows participations of direct gas emissions with greenhouse effect (as percentage of total anthropogenic emissions of these gases) in five economy sectors in 2010. Data in column B show participations of indirect emissions of carbon-dioxide during electrical energy production which fall on individual sectors which are end-users of energy. The emissions are converted into $\mathrm{CO} 2$ equivalents based on potential of global warming in the period of 100 years from the report IPCC Second Assessment Report (2013). Among many different sources of emission of greenhouse gases outside energy sector, agriculture has the most significant role, due to direct impact of agricultural production and to indirect impact of deforestation and change of soil purpose.

Basic possibilities for decreasing carbon emissions in agricultural sector include recuperation of destroyed pastures and agricultural soil. However, there are other possibilities of improvement. A method seriously considered means a change in diet of cattle in order to decrease their methane emission. A more efficient use of fertilizer can potentially reduce agricultural emissions of nitrogen oxide.

Agricultural production, with the use of fertilizers, has an important impact on the cycle of nitrogen circulation. Our atmosphere has $79 \%$ of nitrogen in form of did - nitrogen (N2). This form of nitrogen is an internal one and not 
very useful for mankind. On the other hand, nitrogen in reactive forms, such as nitrates, nitrites and ammonium, is essential for living creatures, because it is an integral element of amino acids and proteins.

In nature, di - nitrogen molecules from atmosphere turn into reactive nitrogen within different biological processes caused by bacteria or through electrical discharge. Today, man converts more di - nitrogen into reactive nitrogen more than the nature does. It happens in complex industrial processes where atmosphere nitrogen is converted into ammonium and other forms of reactive nitrogen which is used for producing urea and other fertilizers.

The process, which many consider the greatest industrial innovation, was developed by two great chemists, Fritz Haber and Carl Bosch, from 1908 to 1912, and solved the problem of nitrogen nutrients shortage, necessary for increasing production of food in the world. The world population, which numbered less than two billion then, could increase to seven billion mainly due to that fact.

Table 2. The use of chemical fertilizers (2002-2010) in certain countries (t/1000 ha)

\begin{tabular}{|c|c|c|c|c|c|c|c|c|}
\hline Years & France & Germany & $\begin{array}{c}\text { Serbia } \\
\text { Montenegro }\end{array}$ & Serbia & Switzerland & Turkey & UK & USA \\
\hline 2002 & 112.51 & 149.02 & 51.66 & & 93.58 & 45.11 & 202.64 & 62.29 \\
\hline 2003 & 121.29 & 151.9 & 44.95 & & 100.66 & 51.51 & 197.09 & 66.16 \\
\hline 2004 & 118.67 & 146.98 & 81.95 & & 106.27 & 51.38 & 180.81 & 67.15 \\
\hline 2005 & 112.25 & 147.5 & 72.46 & & 123.41 & 51.57 & 173.65 & 65.63 \\
\hline 2006 & 112.5 & 132.61 & & 65.34 & 123.57 & 54.35 & 164.2 & 71.3 \\
\hline 2007 & 123.06 & 149.66 & & 87.21 & 112.99 & 54.53 & 164.08 & 70.43 \\
\hline 2008 & 108.15 & 127.81 & & 65.45 & 123.05 & 46.24 & 150.88 & 64.75 \\
\hline 2009 & 98.32 & 129.19 & & 88.13 & 118.73 & 58.2 & 166.78 & 66.8 \\
\hline 2010 & 105.68 & 148.32 & & 43.86 & 118.7 & 55.08 & 171.04 & 70.73 \\
\hline
\end{tabular}

Source: FAOSTAT; http://faostat3.fao.org/browse/E/EF/E

Over-exploitation of nitrogen fertilizers, as shown in chart 2, changes the intensity of nitrogen circulation and creates enormous environmental problems. Nitrogen goes into water flows and then evaporates. a part of reactive nitrogen goes into rivers and seas, causing eutrophication (by over-sedimentation of nutrients); algae flourishing follows, and then decay of bacteria and algae, which leads to reduction of oxygen in water and destruction of sea flora and fauna. A part goes into atmosphere, but not as di - nitrogen but as nitrogen-sub oxide, a greenhouse gas. An analysis of fertilizer usage from 2002 to 2010 encourages because it shows that the usage is decreasing. Third important impact of the system of agricultural production on our planet is destruction of habitat of other species, which leads to disturbance of natural balance and of the food chain. This is particularly related to forest regions, which nowadays jeopardizes irreplaceable biodiversity of forest regions. Modern agricultural production has lead to a very simplified structure of ecosystems to mono-culture, reducing biodiversity to a very limited number of crops and domestic animals.

In agro systems throughout the world in all climate zones there are 12 kinds of crops, 23 kinds of vegetables and 35 kinds of fruit. It is a total of 70 kinds on approximately 1,440 million hectares of arable land in the world, a sharp contrast of diversity of plants can be found on one hectare of rain forest which has over a hundred species of wooden plants (Thrupp, 1998). One of the most important reasons of soil exposure to depletion is destruction of habitat by man.

Usage of pesticides, herbicides and other chemicals in agriculture is one of the most serious reasons of endangering biodiversity and of negative impact on human environment. There are more than 1,500 chemical compounds in use in the world, which form the base of thousands of preparations that are being used in hundreds of millions of tons. A part of these chemicals evaporates, is being washed down or deposed from treatment place so less than $1 \%$ of the matter remains on the desired spots (Kristiforovic - Ilic, 2004). 
Table 3. Usage of pesticides from 1992 to 2010 in individual countries (per square kilometer)

\begin{tabular}{|c|c|c|c|c|c|c|c|}
\hline Years & Germany & France & UK & USA & Switzerland & Turkey & $\begin{array}{c}\text { Serbia and } \\
\text { Montenegro }\end{array}$ \\
\hline 1992 & 2.52 & 4.43 & 4.7 & 2.15 & 4.66 & 0.98 & 0.81 \\
\hline 1993 & 2.11 & 4.73 & 5.26 & 2.12 & 4.46 & 1.02 & 1.14 \\
\hline 1994 & 2.19 & 4.59 & 5.68 & 2.31 & 4.43 & 0.87 & 1.05 \\
\hline 1995 & 2.49 & 4.31 & 5.63 & 2.3 & 4.09 & 1.01 & 0.9 \\
\hline 1996 & 2.63 & 5.03 & 5.78 & 2.39 & 3.91 & 1.12 & 0.89 \\
\hline 1997 & 2.52 & 5.64 & 5.52 & 2.41 & 3.72 & 1.28 & 0.84 \\
\hline 1998 & 2.76 & 5.53 & 5.62 & 2.37 & 3.56 & 1.12 & 0.87 \\
\hline 1999 & 2.49 & 5.88 & 5.95 & 2.44 & 3.48 & 1.23 & 0.91 \\
\hline 2000 & 2.93 & 5 & 3.53 & 2.41 & 3.61 & 1.27 & 0.85 \\
\hline 2001 & 2.78 & 5.09 & 3.66 & 2.31 & 3.58 & 0.97 & 0.91 \\
\hline 2002 & 2.87 & 4.21 & 3.46 & 2.37 & 3.53 & 1.05 & 0.81 \\
\hline 2003 & 2.95 & 3.81 & 3.49 & 2.4 & 3.44 & 1.27 & 0.72 \\
\hline 2004 & 2.89 & 3.89 & 3.59 & 2.5 & 3.23 & 1.08 & 0.74 \\
\hline 2005 & 3.01 & 3.98 & 3.68 & 2.39 & 3.22 & 1.52 & \\
\hline 2006 & 3.19 & 3.65 & 3.17 & 2.41 & 3.16 & 1.31 & \\
\hline 2007 & 3.37 & 3.96 & 3.64 & 2.42 & 4.88 & 1.96 & \\
\hline 2008 & 3.58 & 4.05 & 3.57 & & 4.68 & 1.63 & \\
\hline 2009 & 3.24 & 3.28 & 3.5 & & 5.05 & 1.53 & \\
\hline 2010 & 3.39 & & 2.79 & & 4.81 & 1.59 & \\
\hline
\end{tabular}

Source: FAOSTAT, http://faostat3.fao.org/browse/E/EP/E

Data from chart 3 show that pesticide usage in the last 8 years has risen in Germany and Turkey, while it has largely remained the same in other countries.

For all above mentioned reasons, the agricultural sector is the main factor of anthropogenic environmental loss, and that is why there is great need for changes in agricultural technologies and processes, as well as in manner of soli exploitation so the agricultural systems do not jeopardize planet sustainabiliy.

\section{DIRECTING AGRICULTURAL PRODUCTION TOWARDS SUSTAINABLE DEVELOPMENT}

Considering the complexity of systems of agricultural production, interdependence of soil exploitation, nitrogen and chemical polluters, on endangered crops due to higher temperatures, the answers will have to be different, holistic and carefully suited to local context. Each region will need to establish its own ways to sustainable agriculture. The world needs new green revolution with new kinds of crops, which will be suited to new environmental challenges.

The botanists are working on identifying a gene to create new kinds of crops resistant to drought by crossbreeding.

Agricultural cultures should not only grow better in unfavorable conditions; they should also have a better nutritive value. For example, in The International Rice Research Institute in Los Banos in The Philippines the socalled "golden rice" has been developed, enabling green revolution in producing this crop. A third way is absolutely necessary, and it is called "precise agriculture", meaning economic usage of water, nitrogen and other inputs, so the food would be produced with a smaller impact to the environment (Sachs, 2012). That kind of agricultural production is already spread in developed countries. Precise agriculture includes, for example, a more precise usage of fertilizer so one can decrease volatility and washout of the fertilizer which is not absorbed by the crops.

Precise agriculture depends on information technologies and detailed mapping of soil types, frequently on global positioning system, which can tell a farmer what is going on with a soil and what treatment it should receive. Such a nutrient management can enable huge increase in yield and cut costs. Organic agricultural production represents a way of sustainable food production and it should be supported in the future. With this kind of production, generally speaking, circumstances dominate over threats, but weaknesses dominate over strengths as well (Curic J, Ceranic S, 
2011). This suggests one has to take activities on building a better business environment at some points, such as institutional support, better approach to soil exploitation and financial sources, better technical assistance, better marketing and a clear economic support in agreement with the need to support producers in costs of production certification.

As for developing countries, there is a need to improve relations with foreign partners, which is not possible at farm level, but is through clusters and big companies which create networks of farms or clusters for producing and exporting to developed countries.

The other breakthrough expecting us is better water supplies, for we are exhausting reserves we have. Irrigation on solar energy can play an important role in irrigation technologies, especially when one needs to help small farmers.

Better harvesting, storage and transportation of crops would enable a great progress which could help avoid huge losses which accrue by the time products reach end-user. Better business models of small households would enable production with a small cost of inputs. New business models can improve both value chains and incomes. Changes in agriculture policies can greatly contribute to a sustainable development of agriculture. Economic stimuli in many countries do not favor healthy food. In the US and Europe, subsidizing wheat production has led to over-production and consumption of beef to the extent where it is harmful to health and the environment. A quantity of 10-1 kilograms of wheat required for producing 1 kilogram of beef enormously increases use of fertilizers and water, thus putting high pressure on the environment.

In the USA, these problems are becoming even more complicated lately, for a significant part of annual corn production is turned into ethanol for cars. The strategy of producing ethanol from corn does not cut costs in terms of preserving the environment but it excludes a huge portion of food production from the food chain.

The conclusion is that the road to sustainable development includes a change in behavior, public awareness, political and individual responsibility. By introducing new technologies which can dramatically reduce pressure on the environment, we will have an economy and way of life more resistant to environmental changes.

\section{CONCLUSION}

The world population is constantly growing and warnings about food shortage are ever more vocal. The mankind is changing the Earth's climate, availability of clean water, chemical composition of oceans and habitats of other species. The impact is so big our planet is experiencing obvious changes of major processes which condition life on the planet.

Complex climate changes impact the availability of inputs necessary for agricultural production. Higher temperatures jeopardize soil humidity and decrease crop productivity. Warming will be followed by changes in patterns of regional and global precipitations. In some parts of the world, the food production will be impossible.

On the other hand, agricultural production greatly contributes to pollution due to modern agro technical measures. The production is the largest source of greenhouse gases. CO2 emissions do not only change climate, they impact the ocean acidification.

Modern agricultural production is based on widespread use of pesticides and herbicides, and these chemicals can contaminate soil sufficiently to destroy biodiversity in agricultural areas.

From all above presented, we can conclude that interdependence of agricultural production and the environment is multiple and works both ways. On one hand, there are environmental changes which jeopardize production and, on the other, agriculture seriously damages the environment.

Establishment of sustainable system of agricultural production is necessary in order to feed a growing number of people on Earth with decreased pressure on major systems of the environment.

Sustainable agricultural production and food supply are still facing us with many unsolved issues. It is an area which will require the most intensive solving of issues on local level.

\section{LITERATURE}

BROWN, L. (2000): 'How Water Scarcity Will Shape the New Century' - keynote speech presented at Stockholm Water Conference, August 14, 2000, Earth Policy Institute, available on

:http://www.earth-policy.org/press_room/C68/stockholm_transcript

BIRKÁS, M. (2008): Environmentally-sound adaptable tillage. Akadémiai Kiadó. Budapest, 1-354 pp.

CURIĆ, J., CERANIĆ, S. (2011): Lanac vrednosti organske hrane u Srbiji. Zbornik naučnih radova Instituta PKB Agroekonomik, vol. 17, br. 3-4, str. 185-191

VÁRALLYAY, G. (2011): The 4th international scientific/professional conference. Control of soil processes for environment protection. Agiculture in nature and environmental protection. Proceedings.1-3. june, 2011, 23-36., Vukovar. Republic of Croatia 
ILIĆ, D., KOSTIĆ-NIKOLIĆ, S., STEFANOVIĆ, S. (2011): Neracionalno korišćenje vodnih resursa, Zbornik radova, Prvi simpozijum o upravljanju prirodnim resursima( $1^{\text {st }}$ Symposium of Natural Resources Management), Fakultet za Menadžment, Zaječar, Megatrend univerzitet, Beograd, str.237, (available on:

http://www.fmz.edu.rs/pages/05_arhiva/simpozijum/download/1_snrm_2011_zbornik.pdf)

Intergovernmental panel on climate change (2013):Summary for Policymakers, Climate Change 2013, The Phisical Science Basis, Contribution of Working Group I to the Fifth Assessment Report of the Intergovernmental Panel on Climate Change, Cambridge Universiti Press to the UN General Assembly, govor uGeneralnoj skupštini UN, Njujork, available on: http://www.ipcc.ch/pdf/assessment-report/ar5/wg1/WGIAR5_SPM_brochure_en.pdf

KOVAČEVIĆ, D., \& LAZIĆ, B. (2012): Savremeni pravci razvoja poljoprivrede i zahtevi u oplemenjivanju biljaka i korišćenju zemljišta. Genetika, 44(1), 201-216.

KRISTOFOROVIĆ-ILIĆ, M. (2004): Životna sredina i pesticidi. Medicinski pregled, 57(11-12), 523-535

KRAMER, K. J.,AND MEEUSEN, M. (2003): Sustainability in the Agrofood Sector. In Halberg, N. (ed.), Life Cycle Assessment in the Agri-food sector(pp. 182-189). Retrieved March18, 2011, available on

: http://www.lcafood.dk/lca_conf/DJFrapport_paper_2_poster.pdf

MADDISON, A. (2006): The World Economy, Organization for Economic Cooperation, and Development, Nature Climate Change No3, str. 26

SACHS, J.(2014): The age of Sustainable Development, Center for International Relation Sustainable Development, Beograd Sustainable Development Solutions Network Thematic Group on Challenges of Social Inclusion (2013): Achieving Gender Equality, Social Inclusion, and Human Rights forAll, Challenges and Priorities for the Sustainable Development Agenda, Sustainable Development Solution Network, Njujork

Sustainable Development Solutions Network SDSN (2013a): An Action Agenda for Susainable Development, Susainable Development Solutions Network, Njujork, str.2,5

Sustainable Development Solutions Network Thematic Group on Sustainable Agriculture and Food Systems (2013b): Solutions for Sustainable Agriculture and Food Systems, Technical Report for thePost-2015 Development legenda, Sustainable Development Solution Network, Njujork

Thrupp, L.A.(1998): Cultivating diversity: Agrobiodiversity and food security. World Resources Institute, Washington, DC.

UN DEPARTMENT OF EKONOMIC AND SOCIAL AFFAIRS POPULATION DIVISION, (2013): “World Population Prospects: The 2012 Revision”, http:// esa.un.org/wpp/Excel-Data/population.htm.

UNITED NATIONS ENVIRONMENT PROGRAMME (2014): Assessing Global Land Use, Balancing Consuption wit Sustainable Suuply. A Report of the Working Group on Land and Soils of the International Resource Panel, United Nations Environment Programme, Nairobi.

\title{
MEĐUZAVISNOST POLJOPRIVREDNE PROIZVODNJE I ŽIVOTNE SREDINE I PUT KA ODRŽIVOM RAZVOJU
}

\author{
Jasmina CURIĆ, Bahrija KAČAR, Selma IKIĆ
}

\section{REZIME}

Izvod: Održivost poljoprivredne proizvodnje u svetu nalazi se u ozbiljnoj krizi.Međuzavisnost poljoprivredne proizvodnje i životne sredine je višestruka i kauzalnost deluje u dva pravca. S jedne strane,postoje ekološke promene koje ugrožavaju proizvodnju hrane a sa druge, istovremeno, poljoprivreda, onakva kakva je danas, ozbiljno ugrožava životnu sredinu. Sami sistemi poljoprivredne proizvodnje ugrožavaju buduću proizvodnju. Cilj rada je da se istraže uzroci i ograničenja održivog razvoja poljoprivrede u svetu, pri čemu autori posebno ističu: emisije gasova sa efektom staklene bašte, poremećen ciklus kruženja azota i uništavanje biodiverziteta.

Metodološkim okvirom istraživanja, primenom metoda analize sadržaja postojeće domaće i strane literature, metodom komparacije i sinteze, istraženi su faktori međuzavisnosti poljoprivredne proizvodnje i životne sredine kao i mogućnost usmeravanje poljoprivredne proizvodnje u pravcu održivog razvoja. Autori predlažu da pristup ka održivom razvoju treba da bude holistički i brižljivo prilagođen region i lokalnom kontekstu

Ključne reči: poljoprivreda, životna sredina, održivi razvoj

Received / Primljen: 16.08.2016.

Accepted / Prihvaćen: 29.09.2016. 